\title{
Hemp Made Bio-Composites
}

\author{
Arta Seile ${ }^{1}$, Dana Belakova ${ }^{2},{ }^{1,2}$ Institute of Design Technologies, Riga Technical University
}

\begin{abstract}
Hemp cultivation is one of the possibilities to use agricultural land of Latvia. Mechanical and physical properties of hemp fiber and its chemical structure is suitable for using as a reinforcement, but polypropilene (PP) fibers and PolyLactic Acid (PLA) fibers as a matrix for bio-composites. Compression molding is the most common composite processing technology. Composites with the content of $20 \%-40 \%$ of natural fiber could provide optimal mechanical properties. The demand for bio-composites with improved properties will be increasing in the future. Sandwich structure of bio-composite is one of the ways to protect natural fiber from heating degradation.
\end{abstract}

Keywords - Bio-composites, hemp fibers, polypropilene fibers, PolyLactic Acid fibers, nonwoven.

\section{INTRODUCTION}

Following general today's world trends, which are focused on saving non-renewable resources, wider use of renewable resources, reducing environmental impact, there is a rising necessity to use new and more suitable materials. Trends in a number of industries indicate the need to replace existing materials with lighter material structures.

The mentioned aspects are a challenge to develop new materials that consist of naturally renewable resources.

In the paper are studied bio-composites made from hemp nonwovens.

\section{REINFORCEMENT OF NATURAL FIBERS}

Hemp (Canabis sativa) is a renewable resource and a traditional plant for all Latvian regions. Agricultural land is considered as a resource in Latvia but it has not been fully used over the past 20 years. There are large areas of agricultural land in Latvia which are not cultivated and are either neglected or overgrown. It has been stated that as much as 147.6 thousand ha or $49 \%$ of all overgrown and uncared land area in 2011 could be used (1). Compared to other EU countries agricultural land in Latvia has the lowest gross value added per 1 ha. It is 5.4 times lower than the EU average and 2.9 times lower than in the new Member States that joined the EU after the 2004 (2), (3).

Latvia already has experience in hemp cultivation - hemp was intensely grown in collective farms until the 1960s (4). After regaining independence first hemp fields were recorded only in 2008 (5). The time span has been too long for the hemp industry to survive to present days. In order to restore, to promote and to develop the hemp growing and processing industry two societies have been founded in Latvia: Latvian Industrial Hemp Association and The Flax and Hemp Processing Cluster. In 2012 about 600 hectares of hemp were sown in Latvia as compared to 200 ha in 2011. In 2012 about 394 ha (41 farms) was sown with certified seed in accordance with the EU THC monitoring requirements, 140 ha ( 19 farms) was sown with cannabis sativa seeds of different origin and 60 ha with Finola oilseed variety (6).

In the context of EU, the widest area of hemp is grown in France (7), but according to the report of the European Commission, hemp areas in EU were decreasing during the period from 2006 and 2008.

Appropriate selection of hemp (fiber or seed-producing plants) and growing conditions is an important breeding goal.

Physical and mechanical properties of hemp fiber are affected by several factors such as the cannabis plant variety, climatic conditions (location, weather conditions in certain seasons), soil composition (hemp improving soil structure and its purity from heavy metals), the amount of fertilizer, plant density, crop harvesting, etc. Mechanical and physical properties of hemp and flax fiber are reported in Table I.

TABLE I

Mechanical and Physical Characteristics of Hemp and Flax Fibers (8) $-(12)$

\begin{tabular}{|l|c|c|}
\hline \multicolumn{1}{|c|}{ Properties } & Hemp & Flax \\
\hline Density $\left(\mathrm{g} / \mathrm{cm}^{3}\right)$ & 1.48 & 1.4 \\
\hline Young's modulus $(\mathrm{GPa})$ & 70 & $60-80$ \\
\hline Elongation at break $(\%)$ & $1.6-2.2$ & $2.7-3.2$ \\
\hline Tensile strength $\left(10 \mathrm{E} 6 \mathrm{~N} / \mathrm{m}^{2}\right)$ & $550-900$ & $800-1500$ \\
\hline Tensile strength $(\mathrm{MPa})$ & $310-800$ & $343-700$ \\
\hline $\begin{array}{l}\text { Tensile strength at break } \\
(\mathrm{MPa})\end{array}$ & $285-1735$ & 840 \\
\hline Fracture stress $(\mathrm{MPa})$ & 690 & $345-1035$ \\
\hline Degree of polymerisation & 2200 & $2300-8000$ \\
\hline Degradation temperature $\left({ }^{\circ} \mathrm{C}\right)$ & from 150 & from 150 \\
\hline Moisture absorption $(\%)$ & 8 & 7 \\
\hline Moisture content $(w t \%)$ & $10.8-12$ & 10 \\
\hline
\end{tabular}




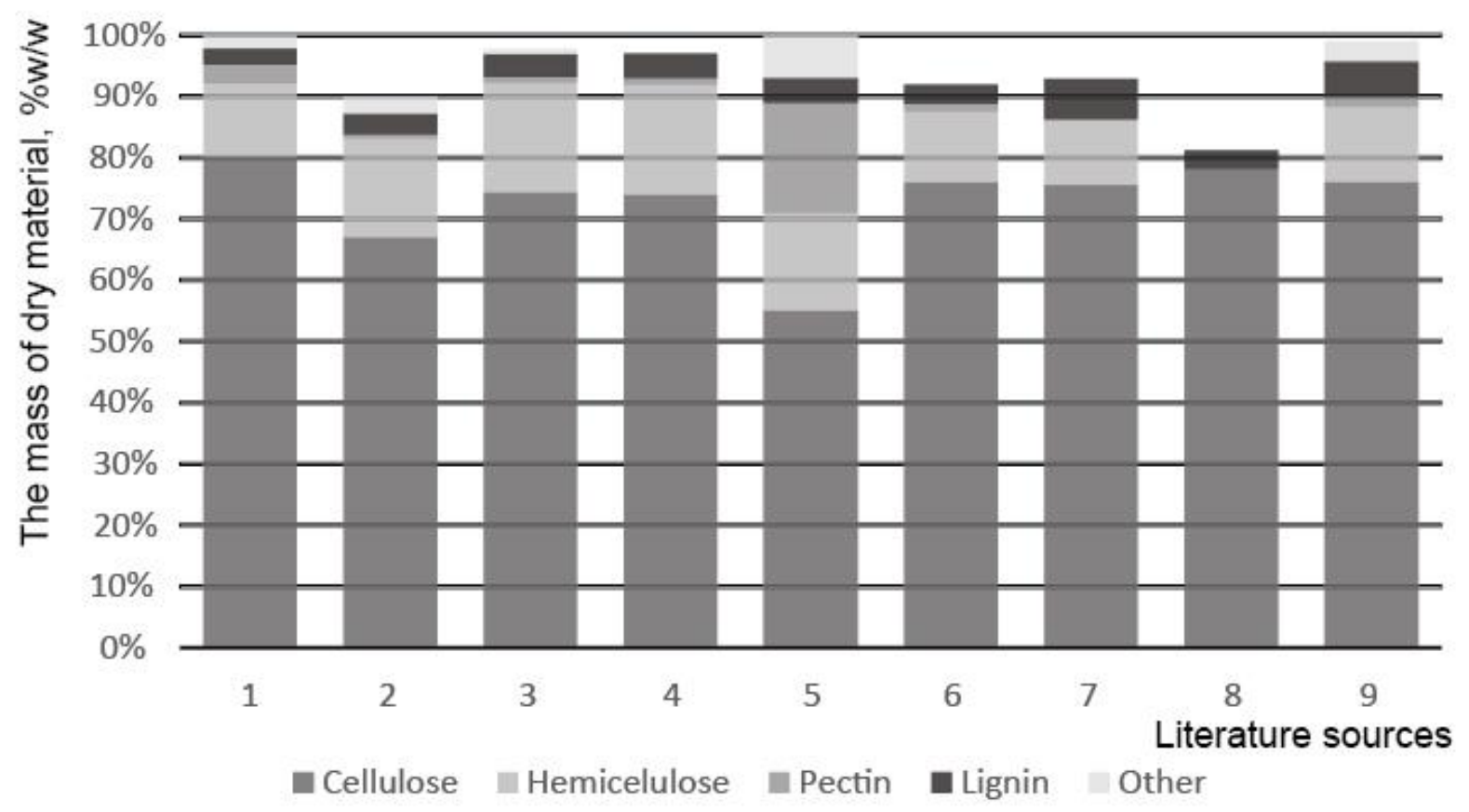

Fig. 1. Hemp fiber biochemical structure: (9, Source 1), (11, Source 2-9).

Hemp fibers are hydrophilic and absorb moisture.

Cellulose, hemicellulose, lignin, pectin, fats and waxes are the main components of hemp fiber chemical structure. Different sources of literature (see Fig. 1) show different ratio between hemp biochemical components. One component can vary for about $20 \%$. Chemical structure of hemp fiber like physical and mechanical properties is affected by plant variety, climatic conditions, soil composition, crop harvesting, etc.

One of the main disadvantages of natural fibers in reinforcement of composites is the poor compatibility between fiber and matrix.

\section{BIO-POLYMER MATRIX}

Biopolymers are composed of polysaccharides such as cellulose, starch, of microorganisms and fungi derived carbohydrate polymers and animal proteins such as wool, silk, gelatine and collagen. The EU and USA standards have different requirements to biopolymers at the end of the lifecycle. Ideally, biopolymers should be obtained from biomass, but at the end of the life cycle of the polymer they must be broken down in the soil, so the process can begin again. Depending on the type of recycling, biopolymers can be recycled by composting, use of gasification and combustion. Composting can be accomplished in two ways: home composting and industrial composting. In some cases, polymers of biological origin cannot be completely divided - usually thermosetting polymers, such as vegetable oil-based polyurethane, and synthetic polymer may be biodegradable, such as polyvinyl alcohol (13).

Composites from polypropilene (PP) and polylactide (PLA) polymer matrix will be explored in this project.

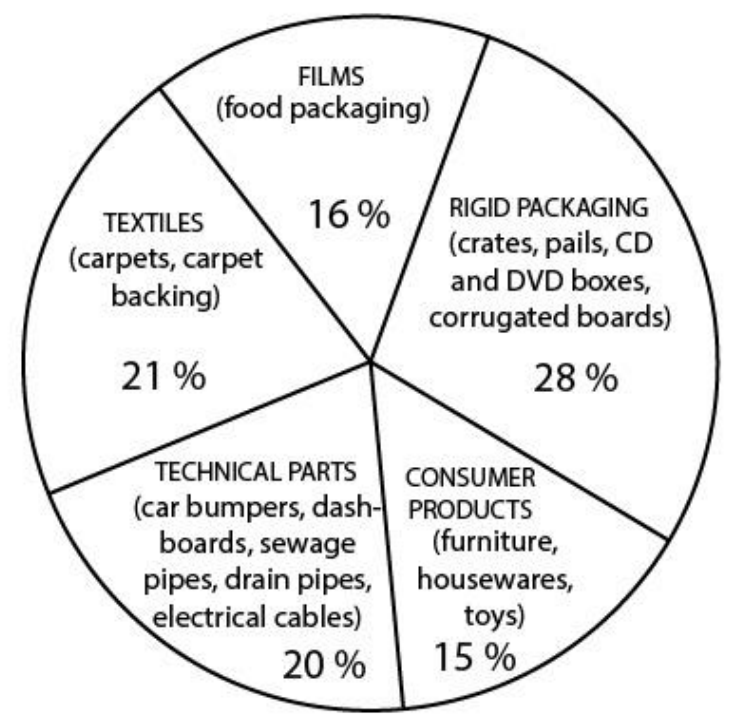

Fig. 2. Use of PP (14).

PP belong to the group of polyolefins. It is a semi-crystalline material and is obtained by polymerization reaction, during which it is polymerized monomer of PP. PP is most often produced in the form of films which are mainly designed for packaging production, while fibers are used in different types of textiles.

The scope of polymer can be greatly enhanced by addition of polymer substances such as fillers, pigments and elastomers. The main use of PP is shown in Fig. 2. PP is one of two most commonly used thermoplastics in practice of producing natural fiber reinforced composites (15). PP component in the biocomposite is recyclable. One of trends in the composite producing industry, especially in the automotive 
industry, is the replacing of new polymers with recycled polymers. This trend is also observed in use of recycled PP fibers. The benefit of using recycled fibers is not only ecological but also economical - recycled fibers are cheaper than virgin fibers.

PLA is a synthetic biopolymer fiber that is the first manmade fiber. It is made from $100 \%$ annually renewable resources. PLA is formed of linear macromolecules having in chain (by weight) at least $85 \%$ (16), (17) of lactic acid esters and these esters are derived from naturally occurring sugars.

Lactic acid is produced by fermentation method, for manufacturing also bacteria and fungi may be used. Nowadays PLA life cycle is mainly attributed to the corn. Polymer extraction scheme is shown in Fig. 3.

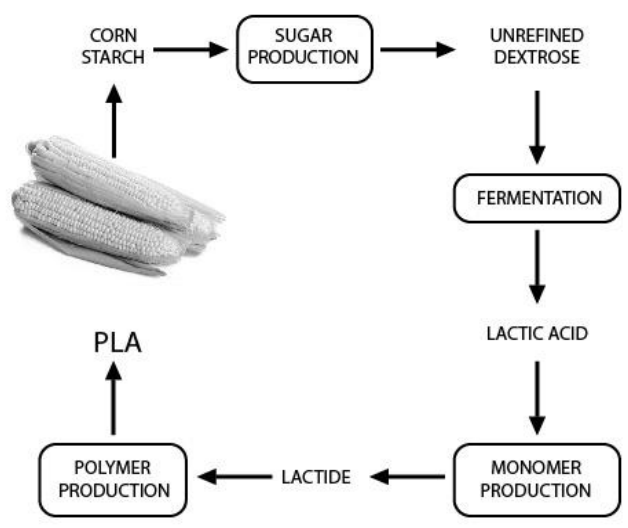

Fig. 3. PLA extraction scheme of corn (18).

PLA properties are similar to PS and PET at room temperature. PLA therefore finds application as packaging material, films and food containers and in disposables (bottles, cups). Such kind of packaging and dishes after using could be placed to so-called compost pile, where they along with other existing organic waste affected by moisture, temperature, soil $\mathrm{pH}$ and the bacterial action undergo material degradation. PLA degradation occurs not only in the soil but also in the sea; it is suitable for degradation under controlled conditions at a temperature of $<60^{\circ} \mathrm{C}$ (19). Items from PLA during biological decomposition process are divided into $\mathrm{CO}_{2}, \mathrm{H}_{2} \mathrm{O}$ and microbial biomass (20); literature sources contain information that PLA degradation occurs from a few months up to a 2-year period (21). This is when the PLA life cycle ends and begins again.

PLA production is mainly influenced by three factors (22) oil prices (the increasing of oil prices have an impact on traditional polymer production costs), legislation (legislation of the EU and its Member States is promoting the use of biopolymers), the company's corporate image (the use of biopolymers in manufacturing process could promote manufacturer brand's sustainable development of public consciousness). PLA production costs are one of the major barriers to commercial production of the polymer and its use.

Structural, thermal, mechanical and barrier properties of the PLA vary depending on the monomer composition (23). PLA is very sensitive to heat, especially when the temperature exceeds $190{ }^{\circ} \mathrm{C}$. Heating PLA at a temperature higher than $190{ }^{\circ} \mathrm{C}$ the average molecular weight becomes considerably lower (24).
Some of the mechanical and physical characteristics of PLA and PP are combined in the Table II.

PLA is suitable for application as the matrix in fiber-filled composites (25).

TABLE II

MECHANICAL AND PHYSICAL CHARACTERISTICS OF PP AND PLA FIBER $(26)-(30)$

\begin{tabular}{|c|c|c|}
\hline Properties & PP & PLA \\
\hline Density $\left(\mathrm{g} / \mathrm{cm}^{3}\right)$ & $0.9-1.16$ & $1.21-1.25$ \\
\hline Young's modulus $(\mathrm{GPa})$ & $1.1-1.6$ & $0.35-3.5$ \\
\hline Tensile strength $(\mathrm{MPa})$ & $30-40$ & $21-60$ \\
\hline Melting point $\left((\mathrm{Tm}){ }^{\circ} \mathrm{C}\right)$ & $160-176$ & $150-162$ \\
\hline $\begin{array}{c}\text { The glass transition } \\
\text { temperature }\left((\mathrm{Tg}){ }^{\circ} \mathrm{C}\right)\end{array}$ & $-10--23$ & $45-60$ \\
\hline
\end{tabular}

\section{BIO-COMPOSITES}

The trends of development of textile bio-composites are largely determined by the European Union Directive 2009/28/ec "Promotion of the use of energy from renewable sources" of the European Parliament. Automotive area is one of the areas where bio-composites are widely used. Automotive industry demands to use lightweight materials for fuel economy (31).

The role of the polymer as a component of composite content is to split and to transfer the operating load to the hemp fiber reinforcement.

Thermoplastic and thermoset processing technologies are used in order to produce a plant based composite, where natural fiber is as reinforcement. The most common composite processing technologies of thermoplastics are compression molding, extrusion, injection molding and long fiber thermoplastic-direct (LFT-D) method (15) and of thermosets: resin transfer molding, sheet molding compound (32). About $35 \%$ parts of the automobile are made by compression molding method. It is possible to produce items with two dimensional and three dimensional structures by compression molding method. It is important that the maximum impression depth of three-dimensional structures could be up to $15 \mathrm{~cm}-20 \mathrm{~cm}$ (33). Thermoplastics start to melt at a specific temperature (34) and owing to the thermal limits of the natural fibers only some low-melting thermoplastics may be used. Thermoplastics have significant viscosity and therefore their good wetting with natural fibers is difficult to achieve (11). In order to achieve the reduction of viscosity it is necessary to increase the temperature of thermoplastics. During the increasing temperature of thermoplastic there is a risk to damage natural fibers. Extensive use of compression molding could be attributed to as an adequate method for manufacturing medium-sized quantities and larger-scaled parts (33). From the view point of production costs, the costs for the molding tools are lower comparing to injection molding. For thermosets, usually epoxy resins, phenolic resins, polyurethanes, polyester, vinyl resins and acrylate resins are used (35). Thermoset composites with compression molding have better thermal properties than the composites with thermoplastic matrix. When choosing between 
the thermoplastic and thermoset matrix it should be noted that the first tends to be more expensive and is not easily recyclable.

In the automotive industry, the most common processing technology for composites reinforced with natural fibers is thermoplastic press molding (61\%), thermosetting plastic press molding $(35 \%)$, press flow molding $(2 \%)$ and injection molding (2\%) (35).

A bio-composite's properties are influenced by a number of variables such as fiber type, environmental conditions, any modification of the fiber, and processing methods of fibers and bio-composites. Interfacial bonding between a natural fiber reinforcement and polymer matrix has a big impact on mechanical properties of bio-composites. Interfacial bonding depends on three factors: mechanical anchoring, physical attractive forces (van der Waals force and hydrogen bond), and chemical bonding between the two (natural fibers and polymer matrix) (11).

\section{HEMP AND PP MADE BIO-COMPOSITE}

Hemp-PP composites have been studied quite extensively to find the best fiber proportion, so that composite inheres the best properties. Hemp amount in hemp-PP composites was prepared in wide range: $20 \%-70 \%$ (36) hemp by weight. In earlier studies it was found that the best short hemp fiber volume was around $20 \mathrm{wt} \%$ - $30 \mathrm{wt} \%$ (37).

Hargitai, Racz and Anandjiwala (36) have studied the best hemp fiber proportion for hemp-PP composite depending on the influence on the effect of water sorption. Researchers report that among four hemp proportion combinations (30 wt $\%$, $40 \mathrm{wt} \%, 50 \mathrm{wt} \%$ and $70 \mathrm{wt} \%$ ) optimal mechanical properties are achieved in composites made from $40 \%$ to $50 \%$ of hemp fibers by weight. At a higher natural fiber content, a higher water uptake was observed $-7 \%$ water uptake was measured at the lowest fiber content of $30 \%$ and almost $53 \%$ water uptake was observed in composites containing $70 \%$ hemp fiber.

Several researchers have studied the hemp fiber treatment with $\mathrm{NaOH}$ and $\mathrm{Na}_{2} \mathrm{SO}_{3}$ solutions on the future properties of Hemp/PP composite. In the research of Beckermann and Pickering (38) the treated fibers were more thermally stable than untreated fibers and treatments resulted in increase of tensile properties of hemp-PP composites.

Bourmaud and Baley (39) studied the effect of multiple reprocessing on mechanical and thermal properties of hemp-PP composites. They reported that seven cycles of reprocessing did not show significant effect on tensile properties of the composites.

Other manufacturers offer applications where other natural fiber, for example, flax, is used as reinforcement. Techni Lin provides an interior door panel for Opel and Citroen made from $\mathrm{PP}$ and flax fiber. The material is a homogenized mix ranging from $60 / 40 \%$ to $70 / 30 \%$ (8) of PP and natural fiber (flax), both fibers are stretched into a layer of non-woven material. $30 \%-40 \%$ natural fiber ratio is traditionally used for creating the material.
Chen (40) studied nonwoven composites with uniform and sandwich structures. Composites with uniform structure were developed using PP and natural fibers: kenaf/PP (70/30), bagasse/PP (50/50) and ramie/PP (70/30), sandwich composites including kenaf/bagasse/kenaf/ and ramie/kenaf/ramie. Composites were tested on mechanical and thermal properties, and on the effect of moisture. Composites with uniform structure have a higher tensile strength and modulus and a higher flexural yielding stress and modulus than the sandwich structure. Uniform composites had less water absorption but higher swelling rate than the sandwich composites. Dynamic mechanical analysis showed that the uniform composites featured higher softening temperature $\left(140^{\circ} \mathrm{C}\right)$ and melting temperature $\left(160{ }^{\circ} \mathrm{C}\right)$.

\section{HEMP AND PLA MADE BIO-COMPOSITE}

In the sources of literature it is said that the most widely used hemp amount in hemp-PLA composites is $10.20 \mathrm{wt} \%$ and $30 \mathrm{wt} \%$ (28).

Sawpan, Pickering and Fernyhough investigated the potential of hemp fiber as reinforcement for PLA. They found good interaction between hemp fiber and PLA resulted in the increase of Young's modulus by $100 \%$ and of tensile strength of composites containing $30 \mathrm{wt} \%$ fiber by $30 \%$ (28).

\section{CONCLUSION}

In the territory of Latvia, there are enough unused agricultural land resources to undertake industrial hemp cultivation. Given that there is a tradition in cultivating flax in Latvia Considering the tradition of flax cultivation in Latvia, the free agricultural land could be used for growing flax or hemp as an alternative or an additional plant. To increase the benefit of hemp fibers it is necessary to find the best possible usage. Hemp fiber behavior, mechanical and physical properties, and chemical structure is suitable for using it as a reinforcement in composite. Choosing bio-polymer as matrix of composite, hemp could be used as a component of biocomposite. Composites made of natural fiber reinforcement and matrix of PP and PLA fibers were studied in this paper. The first polymer was chosen because of its extensive usage in composites, but the PLA was chosen because of its inherent biodegradability. Composites of PP have been studied more than composites of PLA.

The most commonly used ratio of natural fibers in a composite is $20 \%-40 \%$. This proportion of fibers provides composites with optimal mechanical properties and water uptake.

Bio-composites can have two types of structures: uniform and sandwich type. Sandwich structure of a composite is a way to improve certain properties, for example to reduce swelling rate after water uptake.

In the future the demand for bio-composites with improved properties will increase. The development of composites shows the trend that one kind of natural fibers is enhanced with other types of natural fibers. 


\section{REFERENCES}

1. Latvijas Valsts aug̣̣kopības institūts. Atskaite-ziṇojums par projektu Lauksaimniecības zemes izmantošanas efektivitātes un iespēju novērtējums. 2012.

2. Eurostat. Other Land: Number of Farms and Areas by Agricultural Size of Farm (UAA) [online]. [viewed 7.10.2013.]. Available from: http://appsso.eurostat.ec.europa.eu/nui/show.do?dataset=ef_powood\&la ng=n Eurostat.

3. Gross Value Added of the Agricultural Industry - Basic and Producer Prices [online]. [viewed 7.10.2013.]. Available from:

http://epp.eurostat.ec.europa.eu/tgm/download.do?tab=table\&plugin=1\& language $=$ en $\&$ pcode $=\operatorname{tag} 00056$

4. Latvijas industriālo kaņepju asociācija. Pamatinformācija un vispārīgi ieteikumi kaṇepju audzētäjiem. 2011. 1.-3.1pp. [online]. [viewed 02.09.2013.]. Available from: Ieteikumi_audzetajiem_2011_LIKA.pdf

5. Freivalde, L., Kukle, S., Ulme, A. Salīdzinoša kaṇepju škiedru ilgizturības analize. Scientific Journal of Riga Technical University. Material Science. Textile and Clothing Technology. Riga: RTU Publishing House, 2010, pp. 134-138. ISSN 1691-3132.

6. Latvijas industriālo kaņepju asociācijas ziņojums (2013). Nozaru ekspertu ziņojumi, pielikums Nr. 1. Nozare - kaņepes.

7. Eiropas komisijas lauksaimniecības un lauku attīstītbas zinojums par liniem un kañepēm ES [online]. EIHA [viewed 03.09.2013.]. Available from: http://www.eiha.org/attach/553/09-02_C1_Flax_hemp_presentation _26_February_2009_circa.pdf

8. Rosato, D. Green Automotive Applications Remarkable Variety. 2008. [online]. [viewed 23.04.2014.]. Available from:http://www.omnexus.com/ resources/print.aspx?id=19381

9. Marrot, L., Lefeuvre, A., Pontoire, B., Bourmaund, A., Baley, C. Analysis of the hemp fiber mechanical properties and their scattering (Fedora 17). Industrial Crops and Products, vol. 51, 2013, pp. 317-327. http://doi.org/2wc

10. Netravali, N., Chabba, S. Composites get greener. Materials Today MATER TODAY, 2003, vol. 6 Issue 4, pp. 22-29. http://doi.org/fr59xs

11. Shahzad, A. Hemp fiber and its composites - a review. Journal of Composite Materials, [online]. 2012, vol. 46, no. 8, pp. 973-986 [viewed 22.01.2014.] Available from: http://doi.org/ck7cvw

12. Müssig, J., Fischer, H., Graupner, N., Drieling, A. Testing Methods for Measuring Physical and Mechanical Fibre Properties (Plant and Animal Fibres). Müssig, J. Industrial Applications of Natural Fibres. A John Wiley and Sons, Ltd., Publication. 2010, pp. 301-302.

13. Johnson, R. M. Biopolymers. Smithers Rapra Technology. 3 p. [online]. [viewed 29.07.2013.]. Available from: http://site.ebrary.com/id/ 10236793 ?pgd $=12$

14. The Essential Chemical Industry, CIEC Promoting Science at the University of York, [online]. [viewed 2.04.2014.]. Available from: http://www.essentialchemicalindustry.org/polymers/polypropene.html

15. Faruk, O., Bledzki, A. K., Fink, H.-P., Sain, M. Biocomposites reinforced with natural fibres: 2000 - 2010. Progress in Polymer Science, vol. 37, Issue 11, 2012, pp. 1552-1596. http://doi.org/2wd

16. Ministru kabineta noteikumi Nr. 272. Noteikumi par tekstilškiedru sastāva norādī̌̌anu tekstilizstrādājumu mark̦ējumā [online]. [viewed 1.08.2013.]. Available from: http://likumi.lv/doc.php?id=106684

17. Eiropas Komisijas Direktīva 2004/34/EK (2004. gada 23.marts) [online]. [viewed 1.08.2013.]. Available from: http://eurlex.europa.eu/Notice.do?mode=dbl\&lang=lv\&ihmlang=lv\&lng1=lv,lv\&lng2 =bg,cs,da,de,el,en,es, et,fi,fr,hu,it,lt,lv,mt,nl,pl,pt,ro,sk,sl,sv, \&val=343150:cs

18. The Sustainability of Nature WorksTM Polylactide Polymers and IngeoTM Polylactide Fibers a: an Update of the Future. Initiated by the 1st International Conference on Bio-based Polymers (ICBP 2003), November 12-14 2003, Saitama, Japan. Macromolecular Bioscience, pp. 551-564.

19. Camann, A., Dragsbaek, K., Krol ,S., Sandgren, J., Song, D. Properties, Recycling and Alternatives to PE Bags. [online]. [viewed 24.04.2014.]. Available from: http://www.wpi.edu/Pubs/E-project/Available/E-project030510-145034/unrestricted/Properties,_Recycling_and_Alternatives to_PE_Bags.pdf

20. Dukal̦ska, L., Muižniece-Brasava, S. Dabai draudzìgie, biodegradējamie materiāli. Prezentācija. 34 lpp. [online]. [viewed 9.08.2013.]. Available from: http://Biodegradejamie_mat_Zinatnieku_kafeinica-7.12.2010.pdf
21. Hu, R., Lim, J.-K. Fabrication and Mechanical Properties of Completely Biodegradable Hemp Fiber Reinforced Polylactic Acid Composites. J Compos. Mater., 2007, vol. 41, no 13, pp. 1655-1669. http://doi.org/fg2bm9

22. Södergård, A., Stolt, M. Industrial production of high molecular weight poly (lactic acid). Poly (lactic acid): Synthesis, Structures, Properties, Processing, and Applications, edited by Auras R., Lim L.-T., Selke S. E. M. and Tsuji H. John Wiley \& Sons. Inc., 2010, pp. 27.

23. Johnson, Brandon, M., Bernel, Zachary, E. Materials Science and Technologies: Biodegradable Materials: Production, Properties and Applications. Rojan P. John, G.S. Anisha, Nimisha R. Nair, et al. Chapter 4: Poly Lactic Acid: An Environmentally Friendly Biopolymer. Nova Science Publishers, Inc., eISBN: 9781621001652, pISBN: 9781611228045, 2011, pp. 251 (83).

24. Albertsson, A-C., Varma, I. K., Lochab, B., Finne-Wistrand, A., Kumar, K. Design and synthesis of different types of poly (lactic acid). Poly (lactic acid): Synthesis, Structures, Properties, Processing, and Applications, edited by Auras R., Lim L.-T., Selke S. E. M. and Tsuji H., John Wiley \& Sons. Inc., 2010, pp. 43. http://doi.org/fhq8g6

25. Van den Oever, M., Bos, H. Composites Based on Natural Resources. Müssig, J. Industrial Applications of Natural Fibres. A John Wiley and Sons, Ltd., Publication, 2010, pp. 439-447.

26. Koronis, G., Silva, A., Fontul, M. A review of adeguate materials for automotive applications. Composites: Part B. 44, 2013, pp. 120-127. http://doi.org/2wf

27. Thomas, S., Pothan,L. Natural Fiber Reinforced Polymer Composites: From Macro to Nanoscale, 2009, pp. 115.

28. Sawpan, M. A., Pickering, K. L., Fernyhough, A. Hemp Fibre Reinforced Poly (lactic acid) Composites. Advanced Materials Research. vol. 29-30, 2007, pp. 337-340. http://doi.org/cm6t8c

29. Ashby, M., Johanson, K. Materials and Design. The Art and Science of Material Selection in Product Design. Elsevier, 2002, p. 188.

30. Van de Velde K., Kiekens, P. Biopolymers: overview of several properties and consequences on their applications. Department of Textiles, Ghent University, Belgium. 11 Sept. 2011 [online]. [viewed 1.10.2014.]. Available from: http://biogeneral.com/pdfs/bioab_1.pdf

31. Stewart, R. 2009. Lightweighting the automotive market. Reinforced plastics. March 2009, vol. 53, Issue 2, pp. 14-21. http://doi.org/bkn5zz

32. Rouison, D, Sain, M, Couturier, M. Resin transfer molding of natural fiber reinforced composites: cure simulation. Composites Science and Technology. 200, vol. 64, Issue 5, pp. 629-644. http://doi.org/b7gz3k

33. Huber, F., Graupner, T., Müssig, J. Natural Fibre Composite Processing: a Technical Overwiev. Müssig, J. Industrial Applications of Natural Fibres. A John Wiley and Sons, Ltd., Publication, 2010, p. 408.

34. Prömper, E. Natural Fibre - Reinforced Polymers in Automotive Interior Applications. Müssig, J. Industrial Applications of Natural Fibres. A John Wiley and Sons, Ltd., Publication, 2010, p. 424.

35. Piotrowski, S., Carus, M. Natural Fibres in Technical Applications: Market and Trends. Müssig, J. Industrial Applications of Natural Fibres. A John Wiley and Sons, Ltd., Publication, 2010, p. 79.

36. Hargitai, H., Racz, I., Anandjiwala, R. D. Development of Hemp Fiber Reinforced Polypropylene composites. Journal of Thermoplastic Composite Materials. vol. 21, March 2008, pp. 165-174.

37. Rowell, R.M. A New Generation of Composite Materials from Agrobased Fiber. In: Prasad, P. N., Mark, J. E. and Fai, T. J. (eds). The 3rd International Conference on Frontiers of Polymers and Advanced Materials - Polymer and Other Advanced Materials: Emerging Technologies and Business Opportunities. 1995.

38. Beckermann, G. W., Pickering, K. L. Engineering and evaluation of hemp fiber reinforced polypropylene composites: Fibre treatment and matrix modification. Compos. Part A-Appl. Science and manufacturing, 2008, vol. 39, Issue 6, pp. 979-988. http://doi.org/fqmqdg

39. Bourmaud, A., Baley, C. Investigations on recycling of hemp and sisal fiber reinforced polypropylene composites. Polym. Degrad. Stabil., 2007, vol. 92, Issue 6, pp. 1034-1045. http://doi.org/fv6t6d

40. Chen, Y., Chiparus, L., Sun, I., Negulescu, I., Parikh, D. V., Calamari, T. A. Natural Fibers for Automotive Nonwoven Composites. Journal of Industrial Textiles. 2005, vol. 35. [online]. [viewed 23.07.2014.]. Available from: http://jit.sagepub.com/content/35/1/47 


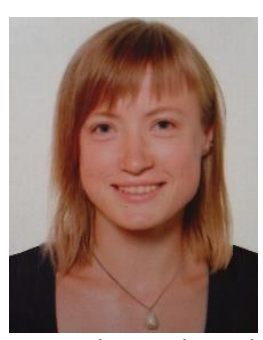

Arta Seile received the Bachelor's degree in Mechanical and Instrumental Engineering in 2009 from the Institute of Transport Vehicle Technologies, Faculty of Transport and Mechanical Engineering, RTU. She received the $M g$. sc. ing. degree in Material Design and Technology from the Institute of Textile Materials, Faculty of Materials Science and Applied Chemistry, RTU, in 2011. Since 2012, she has been a Doctoral student with the Institute of Design Technologies, RTU.

Her work experience includes practice with RWTH Aachen, "JT Studio" Ltd. (as architect technician), "Z4" Ltd (as assistant architect)

Address: Institute of Design Technologies, Riga Technical University, Azenes Str. 18, Riga, LV-1048, Latvia.

E-mail: Arta.Seile@rtu.lv

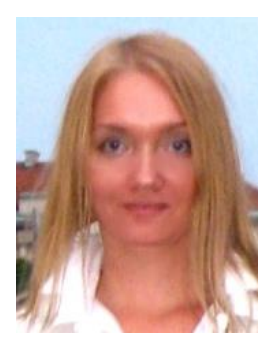

Dana Belakova holds the $\mathrm{PhD}$ degree.

Since 2003, she has been a Researcher and Assistant Professor with the Institute of Design Technologies, Faculty of Materials Science and Applied Chemistry, Riga Technical University.

Her fields of research are: work methods in designing, estimation of time standards, improvement of work time estimation in sewing companies.

Address: Institute of Design Technologies, Riga Technical University, Azenes Str. 18, Riga, LV-1048, Latvia.

E-mail: Dana.Belakova@rtu.lv

Arta Seile, Dana Beḷakova. Biokompozīti no kaṇepēm

Latvijā ir pietiekami daudz lauksaimniecībā neizmantotu zemju resursu, lai nodarbotos ar rūpniecisku kaṇepju audzēšanu. N̦emot vērā senās tradīcijas linu audzēšanā, kā kaṇepēm alternatīva vai papildu kultūra varētu tikt audzēti lini. Kaṇepju škiiedru pievienotās vērtības palielināšanai nepieciešams atrast pēc iespējas piemērotāku pielietojumu. Kaṇepju šḳiedru īpašības un ķīmiskā uzbūve ir piemērota, lai tās izmantotu kompozītu izgatavošanā kā stiegrojumu. Literatūras avotos tika pētîti kompozîti, kas izstrāeāti no dabisko šḳiedru stiprinājuma un PP un PLA matricām. PP kompozīiti ir pētīiti daudz vairāk nekā tie, kas izstrādāti no PLA. Dabisko škiedru apstrāde ar $\mathrm{NaOH}$ un $\mathrm{Na}_{2} \mathrm{SO}_{3}$ šḳidrumu padara tās termiski izturīgākas, nekā neapstrādātas škiedras, un škiedru apstrādes rezultātā pieaug kaṇepjuPP kompozìta stiepes īpašības. Visbiežāk kompozītu izgatavošanai izmantotais škiedru îpatsvars sastāda $20 \%$ līdz $40 \%$ dabisko škiedru. Šĩ škiedru proporcija nodrošina kompozītiem optimālas mehāniskās īpašības un pienemamu ūdens uzsūktspēju. Biokompozītiem var piemist 2 veidu struktūras: viendabīga un sendvičtipa (sviestmaižu tipa). Kompozītiem izveidotā sendvičtipa struktūra ir veids, kā uzlabot atsevišķas īpašǐbas, kā, piemēram, lai mazinātu materiāla uzbriešanu pēc ūdens uzsūkšanas. Kompozītu izveidē ir vērojama tendence, ka viena veida dabiskās šḳiedras padara stiprākas ar cita veida dabiskajām šḳiedrām.

\section{Арта Сейле, Дана Бельакова. Биокомпозиты из конопли}

В Латвии достаточно неиспользованной сельскохозяйственной земли, которую можно использовать для промышленного вырашивания конопли. В связи с давней традицией выращивания льна, в качестве альтернативы или в дополнение к культуре конопли можно выращивать лен. Для увеличения добавленной стоимости волокна конопли необходимо найти подходящее его применение. Свойства и химическая структура волокна конопли подходит для использования его в производстве композитов в качестве арматуры. В литературе приводятся композитные материалы, изготовленные из натуральных волокон, связующих ПП и ПLA матрицы. Композиты ПП более изучены, чем ПLA. Обработка натуральных волокон жидкостью NaOH и $\mathrm{Na}_{2} \mathrm{SO}_{3}$ делает их более термически устойчивыми, чем необработанные волокна, и в результате обработки волокна улучшаются свойства при растяжении композита конопли-ПП. Наиболее часто используемый удельный вес натуральных волокон при изготовлении композита составляет $20 \%-40 \%$. Эта пропорция волокон обеспечивает оптимальные механические свойства и приемлемую абсорбцию воды композитов. Биокомпозиты могут иметь два типа структуры: однородная и типа «бутерброд». Структура типа «бутерброд» создана как способ улучшить определенные качества композита, например, уменьшить набухание материала после поглощения воды. При изготовлении композитов наблюдается тенденция, при которойодин вид натуральных волокон усиливается другими видами натуральных волокон. 